\title{
Early- and Late-Onset Preeclampsia at a Tertiary Hospital in 2016
}

\author{
Hapsari Kinanti ${ }^{1} \mathbb{D}$, Muhammad Ilham Aldika Akbar² $^{*} \mathbb{D}$, Pudji Lestari ${ }^{3}$
}

${ }^{1}$ Faculty of Medicine, Universitas Airlangga, Surabaya, Indonesia.

${ }^{2}$ Department of Obstetrics and Gynecology, Faculty of Medicine, Universitas Airlangga/Dr. Soetomo General Hospital, Surabaya, Indonesia.

${ }^{3}$ Department of Public Health and Preventive Medicine, Universitas Airlangga, Surabaya, Indonesia.

\section{A B S T R A C T}

Introduction: Preeclampsia is still one of the major causes of maternal morbidity and mortality worldwide. Preeclampsia nowadays has another classification, earlyonset preeclampsia and late-onset preeclampsia. This study aimed to evaluate the differences between early-onset and late-onset preeclampsia in Dr. Soetomo General Hospital, Surabaya in 2016.

Methods: This was an analytic observational study, evaluating the difference between early- and late-onset preeclampsia in terms of maternal data, medical history, and obstetric history. The samples were taken from the medical record of Dr. Soetomo General Hospital, Surabaya from January until December 2016.

Results: In maternal data, early- and late-onset preeclampsia mostly happened in productive age, consisted of 34 patients of early-onset preeclampsia (77.3\%) and 31 patients of late-onset preeclampsia (73.8\%). Early-onset preeclampsia tended to happen in nullipara (42.2\%) and primigravida (35.6\%) women, and late-onset preeclampsia usually happened in multipara (43.9\%) and multigravida (85.4\%) women. In medical and obstetric history, early-onset preeclampsia mostly had a history of hypertension $(61.7 \%)$, rather than late-onset preeclampsia $(32.7 \%)$. Moreover, there were no significant differences in other variables.

Conclusion: Early-onset and late-onset preeclampsia had a significant difference in parity, gravidity, and hypertension disease.

* Correspondence: dokter_aldi@yahoo.com

JUXTA: Jurnal IImiah Mahasiswa Kedokteran Universitas Airlangga

p-ISSN: 1907-3623; e-ISSN: 2684-9453

DOI: $10.20473 / j u x t a . V 13 I 12022.6-8$

Open access under Creative Commons Attribution-ShareAlike 4.0 International License (CC-BY-SA)
ARTICLEINFO

Article history:

Received 28 October 2021

Received in revised form 20

December 2021

Accepted 21 December 2021

Available online 5 January 2022

Keywords:

Female empowerment,

Hypertension,

Pre-eclampsia,

Pregnancy. 


\section{Introduction}

The death of a mother is an indicator of fatal failure for a health system. The maternal mortality ratio (MMR) in Indonesia is still one of the highest in Southeast Asia. ${ }^{1}$ Preeclampsia is one of the causes of maternal mortality and morbidity aside from infection and bleeding. Preeclampsia is a common obstetric complication that can cause multiple organ failure that leads to death. ${ }^{2}$ The incidence of preeclampsia occurs in $10-17 \%$ of pregnancies. ${ }^{3}$ Preeclampsia has been around for more than 100 years, nevertheless, until now the number is still increasing and the exact cause of this disease remains unknown. Preeclampsia is also called the disease of theory. 2,4

The modern classification that is widely accepted of preeclampsia was made to give the clinician a better understanding of the disease. ${ }^{3}$ Early-onset and late-onset preeclampsia are classified based on their gestational age when first diagnosed as preeclampsia. If the gestational age was $<34$ weeks when they were first diagnosed, it is called early-onset preeclampsia. It is called late-onset preeclampsia if the gestational age is $\geq 34$ weeks. $^{3}$

Early-onset and late-onset preeclampsia classification is believed to have a different etiology, clinical manifestation, and outcomes that need different treatment. Early-onset preeclampsia needs more intensive care than late-onset preeclampsia. Some studies also found that higher mortality and morbidity usually happen in early gestational age preeclampsia. Due to these differences, early-onset and late-onset preeclampsia should be considered as different diseases. 2,3,5-7 The timing of disease onset is one of important indicators for disease severity, yet it is still inadequately studied. . $^{3,5}$

This study aimed to provide data on characteristics and risk factors that can help the clinician to predict and identify cases that might be developing to early-onset of late-onset preeclampsia. This study included the history of hypertension, parity, and gravidity, thus health care providers can detect early and give better management.

\section{Methods}

This was a cross-sectional analytic observational study. The study was approved by the Health Research Ethics Commission of Dr. Soetomo General Hospital, Surabaya with number 710 / Panke.KKE / XI / 2017. This study used total data sampling of all preeclampsia patients at Dr. Soetomo General Hospital, Surabaya in 2016. The data was collected using medical records, which include maternal data, medical history, and obstetric history. Collected data was statistically analyzed using IBM SPSS 22.

\section{Results}

There were 112 patients with preeclampsia, 10 of the patients were excluded because they did not have clear gestational age that could not be classified as early-onset or late-onset preeclampsia. 102 patients were divided into two groups, which consisted of 47 patients (46\%) in earlyonset and 55 ptients (53\%) in late-onset preeclampsia.

Maternal data are shown in Table 1, 75\% of the study population were in the age group of $20-35$ years old. Nullipara and primigravida were significantly higher in the early-onset preeclampsia group and were statistically different. It was different with late-onset preeclampsia group which mostly happened in patients who already had a history of parity and multigravida.

The medical and obstetrics history of the study population are shown in Table 2. In early-onset preeclampsia, the group had a significantly higher history of hypertension than in late-onset preeclampsia.

Table 1. Maternal data of study population

\begin{tabular}{|c|c|c|c|}
\hline Characteristics & $\begin{array}{c}\text { Early Onset } \\
\text { Preeclampsia } \\
\mathrm{n}(\%)\end{array}$ & $\begin{array}{c}\text { Late-Onset } \\
\text { Preeclampsia } \\
\text { n(\%) }\end{array}$ & $p$-value \\
\hline \multicolumn{4}{|l|}{ Maternal Age } \\
\hline$<20$ & $2(4.5)$ & $0(0)$ & 0.224 \\
\hline $20-35$ & 34 (77.3) & $31(73.8)$ & \\
\hline$>35$ & $8(18.2)$ & $11(26.2)$ & \\
\hline \multicolumn{4}{|l|}{ Parity } \\
\hline Nullipara & $19(42.2)$ & $8(19.5)$ & \\
\hline Primipara & $13(28.9)$ & $15(36.6)$ & 0.036 \\
\hline Multipara & $13(28.9)$ & $18(43.9)$ & \\
\hline \multicolumn{4}{|l|}{ Gravidity } \\
\hline Primigravida & $16(35.6)$ & $6(14.6)$ & 0.026 \\
\hline Multigravida & $29(64.4)$ & $35(85.4)$ & \\
\hline BMI $\left(\mathrm{Kg} / \mathrm{m}^{2}\right) *$ & $29.1(21.8-47.7)$ & $29.5(24-43.4)$ & 0.646 \\
\hline Education & & & \\
\hline $\begin{array}{l}\text { Elementary } \\
\text { School }\end{array}$ & $1(2.3)$ & $1(2.4)$ & 0.209 \\
\hline $\begin{array}{l}\text { Junior High } \\
\text { School }\end{array}$ & $1(2.3)$ & $3(71)$ & \\
\hline $\begin{array}{l}\text { Senior High } \\
\text { School }\end{array}$ & $39(88.6)$ & $37(88.1)$ & \\
\hline $\begin{array}{l}\text { Higher } \\
\text { Education }\end{array}$ & $3(6.8)$ & $1(2.4)$ & \\
\hline
\end{tabular}

${ }^{*}$ Median (Minimum-Maximum)

Table 2. Medical and obstetrics history of study population

\begin{tabular}{lccc}
\hline Variable & $\begin{array}{c}\text { Early Onset } \\
\text { Preeclampsia } \\
\mathbf{n}(\%)\end{array}$ & $\begin{array}{c}\text { Late-Onset } \\
\text { Preeclampsia } \\
\mathbf{n}(\%)\end{array}$ & $\begin{array}{c}\boldsymbol{p} \\
\text { values }\end{array}$ \\
\hline $\begin{array}{c}\text { Hypertension } \\
\text { Yes }\end{array}$ & $29(61.7)$ & $18(32.7)$ & 0.003 \\
No & $18(38.3)$ & $37(67.3)$ & \\
$\begin{array}{c}\text { Diabetes } \\
\text { Mellitus }\end{array}$ & & & \\
$\quad$ Yes & $4(8.5)$ & $2(3.6)$ & 0.410 \\
No & $43(91.5)$ & $53(96.4)$ & \\
$\begin{array}{c}\text { Renal } \\
\text { Disease }\end{array}$ & & & \\
Yes & $1(2.1)$ & $1(1.8)$ & 1.000 \\
No & $46(97.9)$ & $54(98.2)$ & \\
& & &
\end{tabular}




\begin{tabular}{lccc}
$\begin{array}{l}\text { Abortus } \\
\text { Yes }\end{array}$ & $12(25.5)$ & $10(18.2)$ & 0.368 \\
No & $35(74.5)$ & $45(81.8)$ & \\
$\begin{array}{l}\text { Preterm } \\
\text { Delivery }\end{array}$ & & & \\
$\quad$ Yes & $9(19.1)$ & $7(12.7)$ & 0.374 \\
No & $38(80.9)$ & $48(87.3)$ & \\
$\begin{array}{l}\text { Neonatal } \\
\text { Death } \\
\text { Yes }\end{array}$ & $4(8.5)$ & $2(3.6)$ & 0.410 \\
$\quad$ No & $43(91.5)$ & $53(96.4)$ & \\
$\begin{array}{l}\text { Preeclampsia } \\
\text { Yes }\end{array}$ & $4(8,5)$ & $2(3.6)$ & 0.410 \\
$\quad$ No & $43(91,5)$ & $53(96.4)$ & \\
$\begin{array}{l}\text { Eclampsia } \\
\text { Yes }\end{array}$ & $1(2.1)$ & $0(0)$ & 0.461 \\
No & $46(97.9)$ & $55(100)$ & \\
\hline & & &
\end{tabular}

\section{Discussion}

This study showed that in parity and gravidity characteristics, there was a significant difference between early-onset and late-onset preeclampsia. In early-onset preeclampsia, it mostly happened in nullipara and primigravida, and in late-onset preeclampsia, it happened in multipara and multigravida. The explanation of this finding is the longer duration and expose of sperm, the mother will give a protective effect and reduce the probability to have preeclampsia. ${ }^{8}$ It is supported with maladaptation immune theory which states all primipara tend to have preeclampsia than multipara. ${ }^{9}$ Although primipara has a higher risk to have preeclampsia, it does not mean that multigravida cannot have preeclampsia. Especially in multigravida, change partner could have preeclampsia too. In Indonesia, the women have a long life expectancy, with long-lasting marriage and rare divorce cases. Therefore, preeclampsia mostly happens in multigravida Indonesian women. It shows that sociocultural also affects the epidemiology of preeclampsia. ${ }^{10}$

This study shows that early-onset preeclampsia tends to have higher hypertension history. This finding is similar to previous study which found that history chronic hypertension is one of the risk factors of early-onset preeclampsia. While late-onset preeclampsia is usually connected with familial history of hypertension, it is suspected that there is an association with the genetic aspect. ${ }^{2,5}$ This might be happening because early-onset and late-onset preeclampsia have different pathophysiology. ${ }^{11}$ Chronic hypertension can cause endorgan damage and vascular complication that may be the reason chronic hypertension is related to early-onset preeclampsia. ${ }^{2}$

This study found that primigravida, nullipara, and history of hypertension had a higher number in early-onset preeclampsia. This finding is valuable for the health care providers to identify patient risk for developing preeclampsia and give better management, either prevention or treatment.

\section{Conclusion}

There was a significant difference between early-onset and late-onset preeclampsia. Early-onset preeclampsia mostly happened in nullipara and primigravida. Hypertension was one of the risk factors of early-onset preeclampsia.

\section{CONFLICT OF INTEREST}

The author stated there is no conflict of interest in this study.

\section{REFERENCES}

1. Ahmed S, Fullerton J. Challenges of Reducing Maternal and Neonatal Mortality in Indonesia: Ways forward. Int J Gynecol Obstet 2019; 144: 1-3.

2. Aksornphusitaphong A, Phupong V. Risk Factors of Early and Late Onset Pre-Eclampsia. J Obstet Gynaecol Res 2013; 39: 627-631.

3. E. G, Akurati L, Radhika K. Early Onset and Late Onset Preeclampsia-Maternal and Perinatal Outcomes in a Rural Teritiary Health Center. Int $J$ Reprod Contraception, Obstet Gynecol 2018; 7: 2266.

4. Roberts J, Bell M. If We Know so Much About Preeclampsia, Why Haven't We Cured The Disease? J Reprod Immunol 2013; 99: 1-9.

5. Lisonkova S, Joseph K. Incidence of Preeclampsia: Risk Factors and Outcomes Associated with EarlyVersus Late-Onset Disease. Am J Obstet Gynecol 2013; 209: 544.e1-544.e12.

6. Valensise H, Vasapollo B, Gagliardi G, Novelli GP. Early and Late preeclampsia: Two Different Maternal Hemodynamic States in The Latent Phase of The Disease. Hypertension 2008; 52: 873-880.

7. Myatt L, Redman C., Staff A., Hansson S, Wilson ML, Laivouri H. Strategy for Standardization of Preeclampsia Research Study Design. Hypertension 2014; 63: 1293-1301.

8. Dekker G., Sibai B. The Immunology of Preeclampsia. Semin Perinatol 1999; 23: 24-33.

9. Luo Z, An N, Xu H, Larante A, Audibert F, Fraser WD. The Effects and Mechanisms of Primiparity in The Risk of Pree-Eclampsia: A Systematic Review. Paediatr Perinat Epidemiol 2007; 21: 36-45.

10. Robillard PY, Dekker G, lacobelli S, Chaouat G. An Essay of Reflection: Why does Preeclampsia Exist in Humans, and Why are There such Huge Geographical Differences in Epidemiology? J Reprod Immunol 2016; 114: 44-47.

11. You SH, Cheng PJ, Chung TT, Kuo CF, Wu HM, Chu $\mathrm{PH}$. Population-Based Trends and Risk Factors of Early- and Late-Onset Preeclampsia in Taiwan 2001-2014. BMC Pregnancy Childbirth 2018; 18: $1-11$ 